Research Article

\title{
Knowledge and Practice of Traditional Medicine on Respiratory Disorders
}

\author{
Hari Datt Joshi ${ }^{*}$, Umesh Ghimire ${ }^{1}$, Ravindra Pandeya ${ }^{2}$ \\ 1. Research Assistant. Nepal health Research Council; \\ 2. Research Assistant, Nepal Academy of science and technology
}

\begin{abstract}
Traditional medicine and indigenous knowledge of local traditional healers have considered key healthcare supportive skill for rural population in most developing countries of south Asia including Nepal. There is lack of specific research on use of ethno- medicine on particular diseases like respiratory disorder. Key informants and Informal discussions were conducted for collection of detail information's of local practice of using flora and fauna used as medicine on respiratory disorder. The survey was undertaken to collect information from Malikarjun Village Development Committee (VDC) during March 14 - April14, 2008. Findings revealed that locals were highly dependent on traditional healers for treatment to of respiratory disorder. The mothers practiced their own methods using traditional medicine in acute respiratory infection on the basis of her child age. The current study documented 13 genera of ethno medicinal plants belonging to 11 families and 3 faunal genera. Population of study area is still following the traditional healers and traditional medicine for the treatment of respiratory diseases.
\end{abstract}

Keywords: Traditional medicinal practice, Traditional Healer, Respiratory disorder, ARI, Nepal.

\section{Introduction}

Flora and fauna are the components of living earth and have been used in traditional medicine for several thousand years (1). The knowledge of medicinal flora and fauna has been accumulated in the course of many centuries based on different medicinal systems such as Ayurveda, Unani and Siddha. World Health Organization (WHO) has disclosed that 80 percent of the world's people depend on traditional medicine for their primary health care needs. Along with the use of medicinal flora and fauna in treating

\footnotetext{
*Corresponding Author:

Research Assistant Officer, Nepal Health Research Council, Ramshahpath, Kathmandu, Nepal.

Phone: +977-9841721687

Email: sahara.hari@gmail.com
}

various diseases, there are considerable economic benefits we can get from traditional medicines (2). Most of developing countries until now depend on traditional medicines as the main source of health care support for their rural populations including Nepal (3). Nepal's diverse micro-climatic conditions harbors 118 ecosystems, 35 forest types, 75 vegetation types and about 7000 vascular plants about 700 are considered as medicinal plants (4). Medicinal plants and animals are important natural resources for primary health care as well as commercial commodities for income generation activities for a vast majority of the rural people in Nepal and use of traditional medicine in traditional medical care in the rural areas of the country is an age-old practice, with many of the ethnic groups having their own system of traditional and indigenous healing methods (5). The main 
objective of this study was to document the traditional knowledge and aptitude on medicinal flora and fauna on healing respiratory disorder in remote part of Nepal.

\section{Material and Method}

An observational descriptive study was carried out in health care practice of ethno-medicine to for respiratory disorders at Malikarjun VDC of Darchula dstrict located in western Nepal. The study population was poor, rural and ethnically homogenous with more than $90 \%$ Dhami (Chhetri) households. The geographical setting of remote hilly VDC is $29^{\circ} 42^{\prime} 18^{\prime \prime}$ to $29^{\circ} 44^{\prime} 36^{\prime \prime} \mathrm{N}$ latitude and $80^{\circ} 28^{\prime} 12^{\prime \prime}$ to $80^{\circ} 29^{\prime} 44^{\prime \prime}$ E longitude with altitudinal variation ranging from 1404 to 1990 meter height from sea level. The average rainfall is $1885.3 \mathrm{~mm}$ and average minimum and maximum temperature is around $5.7^{\circ} \mathrm{C}$ and $37.5^{\circ} \mathrm{C}$ respectively for whole Darchula district (6).

The research tool includes descriptive analysis through interaction with local communities. For that key informative questionnaire and informal discussion was conducted. Altogether four key informants were selected including two local healers (Vaidya), a patient of respiratory disorder and a mother whose child was suffering from acute respiratory infection (ARI). Informal discussions were also carried out with local people in each ward of VDC. Participants of informal discussion were the patients of respiratory disorder, whose clinical investigation of respiratory illness was already reported, mothers' having child below five years age and elderly people. Female health research assistants were used as rapporteur for taking valid information while Principle investigator guided the discussion as a moderator. Relevant plant specimens were collected and preserved in herbariums which were then identified in the botanical garden, Godavari. The survey was undertaken during March 142008 to
April14, 2008. Ethical approval was taken from Nepal Health Research Council. Verbal consent was taken from every participant while written consent was taken from local community forest management committee for the collection of plant specimens.

\section{Result}

The population of the study site was found to be poor and ethnically homogenous Dhami (Chhetri) community. The study area was free from industrial and atmospheric pollution. There, we found small scattered settlements and most of the people depend on subsistence farming. Most of the people of that village were illiterate especially women, and many of them even could not speak the national language, Nepali. The houses in village represent typical mountain settlements which are made of stone, mud and the roof is made of slate. It was found that majority of the households had kitchen in the upper stories without partition. The kitchen, door, ventilation size and kitchen height was not appropriate as suggest by national guideline. Most of the people of lower caste work as blacksmith where they used to mould the iron in the fire to make utensils used in agriculture and household. The people of study area spend most of their time inside the ill ventilated house and near the traditional stove where high smoke exposure is one of the risk factor for diseases (7). Indoor smoke was found to be a major risk factor for respiratory disorder in the people of Malikarjun.

There was no primary health care center and the sub health post did not have sufficient equipment, medicine and skilled human resource for the treatment of diseases. People followed their own way of treatment practice which was developed since their ancient parents as told by informative source. Local traditional healers were found key informative source for traditional medicine and local people 
follow them. The patients of respiratory disorder were found to apply traditional medicine for healing practice as referred by traditional healers. The annual report published by sub health post revealed that respiratory disorder is top most diseases in the area. Almost all villagers visited $\mathrm{TH}$ for ethno-medicine, though their frequency for visiting depends on diseases episode. $\mathrm{TH}$ give traditional medicine to local people, suffered child's mother, without any treatment cost. Traditional healer reported that both active and passive treatment methods were applied to child and mother. The child receives medicine at the time of breast feeding and sometimes mother applies the medicine to the nipples externally during breast feeding if the child could not ingest. Medicine was directly given to the child through oral route with milk or sometimes with water to the children above one year. Mother seriously told that it was complicated to save the infants suffered from ARI and child below two years. Mother told, they could recognize the symptoms of life threatening episodes of pneumonia which they expressed in their own terminology, swa-swa hune (difficulty in breathing) Ghyaar Ghhyaar hune (noise breathing) and Kokha hanne (chest-indrawing) as in single word "upsasi" (ARI).
At first they consult with their family head about the ailment and then visit traditional healer and finally go for modern medicine if the illness still continues. In case of elderly, they also prefer to visit the $\mathrm{TH}$ at the initial stage of their ailments and if the illness did not cure by $\mathrm{TH}$, then only they go for modern medicine.

Respiratory diseases like chronic obstructive pulmonary disorder, tuberculosis, bronchial asthma and cough, wheezing, breathlessness, phlegm are related problems of respiratory disorder which were revealed in adult patients. They had strongly followed $\mathrm{TH}$ and $\mathrm{TH}$ recommended medicine, although they were firstly using their own general practice like drinking luke-warm water, milk and bathing by warm water. The $\mathrm{TH}$ healer first collect the flora and fauna, then he extracts the useful parts, which is dried and grind to powder form. THs recommend the medicine to patient according to the age and severity of the illness. THs administer the medicine to their visitor according their own knowledge. The recommended flora and fauna by the $\mathrm{TH}$ is shown in the Table 1 , 2 .

Table 1: Tabulation of Flora used in different ailments of respiratory disorders.

\begin{tabular}{|c|c|c|c|c|c|}
\hline S.N & Botanical name & Family Name & $\begin{array}{l}\text { Local } \\
\text { name }\end{array}$ & $\begin{array}{l}\text { Parts } \\
\text { used }\end{array}$ & Disease \\
\hline 1 & $\begin{array}{l}\text { Achyranthus bidentata } \\
\text { Blume }\end{array}$ & Amaranthacaeae & $\begin{array}{l}\text { Bipya } \\
\text { kuro }\end{array}$ & Root & $\begin{array}{l}\text { Common } \\
\text { cold, fever }\end{array}$ \\
\hline 2 & $\begin{array}{l}\text { Costus speciosus (J.Konig) } \\
\text { Sm. }\end{array}$ & Zingiberaceace & kauchho & Rhizome & Eye infection \\
\hline 3 & Curcuma aromatica Salisb. & Zingiberaceace & banhaldi & Rhizome & $\begin{array}{l}\text { Common } \\
\text { cold,fever }\end{array}$ \\
\hline 4 & Phyllunthus embilica L. & Euphorbiaceae & Aula & Fruit & $\begin{array}{l}\text { Asthama, hair } \\
\text { tonic and } \\
\text { burns }\end{array}$ \\
\hline 5. & Punica grantum L. & Punicaceae & Dadim & Fruit & $\begin{array}{l}\text { Common } \\
\text { cold, cough }\end{array}$ \\
\hline
\end{tabular}




\begin{tabular}{|l|l|l|l|l|l|}
\hline 6 & $\begin{array}{l}\text { Ranunculus laetus Wall.ex } \\
\text { D.Don }\end{array}$ & Ranunculaceae & Aado & Rhizome & $\begin{array}{l}\text { Common } \\
\text { cold, cough }\end{array}$ \\
\hline 7 & $\begin{array}{l}\text { Terminalia chebula } \text { Retz. } \\
8 .\end{array}$ & $\begin{array}{l}\text { Combreatceae } \\
\text { (Gaertn.) Roxb. }\end{array}$ & Harado & $\begin{array}{l}\text { Fruit, } \\
\text { Bark }\end{array}$ & $\begin{array}{l}\text { Cough, } \\
\text { Asthma }\end{array}$ \\
\hline 9. & $\begin{array}{l}\text { Zanthoxylum armantum } \\
\text { DC. }\end{array}$ & Combreatceae & Barado & Fruit & $\begin{array}{l}\text { Tonic for } \\
\text { Asthma }\end{array}$ \\
\hline 10. & Azadirachta indica A. Juss. & Meliaceae & Timur & Fruit & $\begin{array}{l}\text { Cough and } \\
\text { Cold }\end{array}$ \\
\hline 11 & Cladonia sps. & Gramineae & Siru & $\begin{array}{l}\text { Leaf, } \\
\text { Bark, } \\
\text { Fruit }\end{array}$ & $\begin{array}{l}\text { Rough, } \\
\text { Pneumonia }\end{array}$ \\
\hline 12. & $\begin{array}{l}\text { Swertia chirayita } \text { (Roxb. ex } \\
\text { Fleming) }\end{array}$ & Gentianaceae & Lektite & $\begin{array}{l}\text { Whole } \\
\text { plant }\end{array}$ & Cough, ARI \\
\hline 13. & $\begin{array}{l}\text { Cinnamomum zeylanicum } \\
\text { Blume }\end{array}$ & Lauraceae & Dalchini & $\begin{array}{l}\text { Bark, } \\
\text { Leaf }\end{array}$ & $\begin{array}{l}\text { Pneumonia, } \\
\text { Pulmonary } \\
\text { Tuberclusis }\end{array}$ \\
\hline
\end{tabular}

Table 2: Tabulation of Fauna used in traditional medicine in respiratory disorder

\begin{tabular}{|l|l|l|l|l|l|}
\hline S.No & Zoological Name & Order & Local Name & $\begin{array}{l}\text { Organ } \\
\text { Used }\end{array}$ & $\begin{array}{l}\text { Medicinal } \\
\text { uses }\end{array}$ \\
\hline 1. & $\begin{array}{l}\text { Moschus chrysogaster } \\
\text { Hodgson }\end{array}$ & Moshchideae & $\begin{array}{l}\text { Khu khu } \\
\text { Kasturi }\end{array}$ & $\begin{array}{l}\text { Musk } \\
\text { Tuberculosis }\end{array}$ \\
\hline 2. & $\begin{array}{l}\text { Gallusgallus domesticus } \\
\text { Linnaeus }\end{array}$ & Gallifroms & Kalij/Kukhura & Meat & $\begin{array}{l}\text { Cold and } \\
\text { Cough }\end{array}$ \\
\hline 3. & $\begin{array}{l}\text { Hystrix brachyura } \\
\text { Linnaeus }\end{array}$ & Rodentia & Sauda & Meat & Asthma \\
\hline
\end{tabular}

\section{Discussion:}

Locals have followed traditional healing practices for the treatment of respiratory illness. Common cold, cough, wheezing symptoms have been reported and concern diseases are ARI in child and asthma in adult. The method of preparation and administration of medicine in the current study has found similar to previous study (3). However, the practice of formation and administration of traditional medicine could vary as per socio-cultural practices and geographical setting (1). The study conducted on different geographical areas places such as Philippines, Bangladesh, and Pakistan has similar findings of administration and treatment practices (8-10). Homogenous culture has shown similar practices and beliefs. A degree of variation in female autonomy across ethnicity, variation in shyness, variation in interpretation of what constitutes a "problem" and variation in beliefs that uphold decisions (11). The mentioned general sequence of treatment measures could be changed if the children did not cure by even following the biomedical treatment. And at the last, the suffering body and their guardians again went to the TH. They adopt one system according to their perception of care provider, unavailability of preferred system, influence in decision making and economic reason. Mothers seek different treatment measures according to child's severity and different sequence of treatment. The decision making power in the household is often held by household head. For any kind of health seeking behavior, the household head must approve in care seeking for a child. Due to the custom of blaming mothers for not 
taking proper care of their children, mothers did not report illness in the initial stage, so they wait to report ARI at the advance stage. This attitude hinders mother-child kinship. The finding has shown that health workers seemed to be unaware about mother's home remedies and traditional healing practices. The study conducted in South Asian context has demonstrated that biomedicine and traditional practice co-exist in a similar way (9). Traditional healer involved in this study had a very flexible view towards biomedical medicine that they themselves recommend to go to doctors if they cannot cure the children. The positive attitude of the TH could be mobilized to create awareness programs for pneumonia and ARI problem. The health program planners should accept the traditional healer as a source in the community rather than to discourage them. The active intervention program could be necessary for controlling ARI, COPD and other respiratory disorder. About $80 \%$ of the rural population in Asia including Nepal depends upon traditional medicine. Cultural knowledge varies in the utilization of traditional medicine for patient's sickness or human welfare. Dominant heterogeneity in culture and more remoteness is better, as they will have supplementary chance of introducing multi-ethno medicinal uses. This study was conducted in a homogenous community where most of the population was poor and uneducated. Eleven medicinal plant species have been reported to be used on respiratory diseases and 52 species on other health ailments belongs to 35 families. The recorded species relate to minor ailments, mainly those of the skin (15 species), toothache (10) and rheumatic pains (8) in small area of diverse ethnic group (11). Many studies have showed that homogenous populations don't utilize the available flora and fauna due to the limited knowledge and practices. A study of
Peruvian Amazon explained that homogenous population practiced $21 \%$ of the available genera while heterogeneous population of the Mali savannas in Southwest Amazon area of Peru utilize $30 \%$ of the medicinal plant genera found there (12). Education status has been found a major factor in administrating and determining the best practice in traditional medicine or consulting the way of health seeking practice. The study has some limitation. The documented traditional medicine and knowledge practice cannot be explored in national and global level because of small scale research. Though, this study might carry few lacking information of remote part of Nepal at the field of healing practices on ethno medicine particularly in the respiratory disorder.

\section{Conclusion:}

From this study it is quite clear that the homogeneous community of Malikarjun village is rich in heritage of traditional medicine. Though recommended all flora and fauna have not scientifically proved in their phytochemical composition, there is need to conduct phytochemical in biological remedies. Traditional healers have their own way of healing practices by the use of traditional medicine to treat respiratory disorder. Therefore the generated information could be used in future research in manufacturing of drug and policy implementation in biological conservation practices.

\section{References:}

1. Abu-Rabia A: Urinary diseases and ethnobotany among pastoral nomads in the Middle East. Journal of Ethnobiology and Ethnomedicine 2005; $1: 4$.

2. Azaizeh H, Fulder S, Khalil K, Said O: Ethnomedicinal knowledge of local 
Arab practitioners in the Middle East Region. Fitoterapia. 2003;74:98-108.

3. Kisangau DP, Lyaruu HV, Hosea KM, Joseph CC. Use of traditional medicines in the management of HIV/AIDS opportunistic infections in Tanzania: a case in the Bukoba rural district. Journal of Ethnobiology and Ethnomedicine 2007, 3:29.

4. Jha PK. Environment and Man in Nepal. Thailand: Known series No.5, White lotus co. Ltd: Bangkok. 1992.

5. Batugal PA, Jayashree $\mathrm{K}$, Lee SY, Jeffrey $\mathrm{T}$ Oliver (eds). Medicinal Plants Research in Asia, Volume 1: The Framework and Project Workplans. International Plant Genetic Resources Institute - Regional Office for Asia, the Pacific and Oceania (IPGRI-APO), Serdang, Selangor DE, Malaysia. 2004.

6. Pant SR, Dhami NR, Panta, IR. Wild edible plants of Lekam area. Darchula, Far-western Nepal. Scientific World, 2005 July; 3:73-77.

7. Joshi HD, Pandeya R, Dhakal B. Health impact of indoor pollution. $\mathrm{J}$
Nepal Health Res Counc 2009 Oct; 7(15):69-75.

8. Nichter, M. Nichter, M. 1994 Acute respiratory illness: popular health culture and mother's knowledge in the philipines,Medical Anthropology, 15(4): 353-375

9. Stewart KM, Parker BC, Begum JH. Acute respiratory infection (ARI) in rural Bangaladesh:perceptions and practices, Medical Anthropology 1994;15(4):377-394.

10. Hussain R, Lobo MA, Inam B, Khan A, Qureshi AF, Marsh D. Pneumonia perceptions and management: an enthnographic study in urban squatter settlements of Karachi, Pakishtan, Sos Sci Med, 1997; 45(7):991-1004.

11. United Nations children's funds. Health seeking behavior of women in five Safe Motherhood Districts in Nepal. Kathmandu, UNICEF. 1998.

12. Malgras D, Arbres et arbustes guérisseurs des savanes maliennes. In Economie et development (Paris, France), A.C.C.T. Editions Karthala; 1992:478.

\section{Abbreviations:}

$\begin{array}{lll}\text { ARI }: & \text { Acute Respiratory infection } \\ \text { COPD : } & \text { Chronic Obstructive Pulmonary Disease } \\ \text { TH }: & \text { Traditional Healer } \\ \text { VDC }: & \text { Village Development Committee } \\ \text { WHO : } & \text { World Health Organization }\end{array}$

